Menstrual problems in women starting or changing pill

\begin{tabular}{|c|c|c|}
\hline Regimen & $\begin{array}{c}\text { No of } \\
\text { women }\end{array}$ & $\begin{array}{c}\text { No }(\%) \\
\text { complaining } \\
\text { of menstrual } \\
\text { problems }\end{array}$ \\
\hline 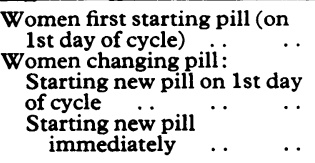 & $\begin{array}{l}125 \\
214\end{array}$ & $\begin{array}{l}23(18) \\
31(15)\end{array}$ \\
\hline Total & 567 & $101(18)$ \\
\hline
\end{tabular}

clinic for their three-monthly appointment and about whom, therefore, we have no information. The table summarises the results for the remaining 567 women, none of whom became pregnant.

Of the 101 women complaining of menstrual problems, 82 had spotting or breakthrough bleeding, 10 had amenorrhoea, and 9 had heavy periods. Although we did not include a control group in our study, the rate of reporting of menstrual problems $(18 \%)$ is not abnormally high in comparison with the rates reported during the first cycle of use of low-dose contraceptives in other investigations. ${ }^{2-4}$

Seventeen doctors using the new regimens were asked their opinion of them; 15 thought they worked well, particularly the "immediate change-over" regimen. It was found to be easier to persuade patients to switch to lowerdose pills if extra precautions were not needed. Patients liked the new regimens and were not upset by spotting or breakthrough bleeding. Since an average supply of sheaths and pessaries for two weeks costs about $£ 1$, a saving of $£ 645$ was made during the course of the study.

Though the manufacturers of pills have expressed their opposition to the new regimens, ${ }^{5}$ we believe them to be effective, acceptable, and economical.

\section{Cynthia Phillips}

Community Health Offices,

Oxfordshire AHA(T)

Oxford

MaRTin Vessey

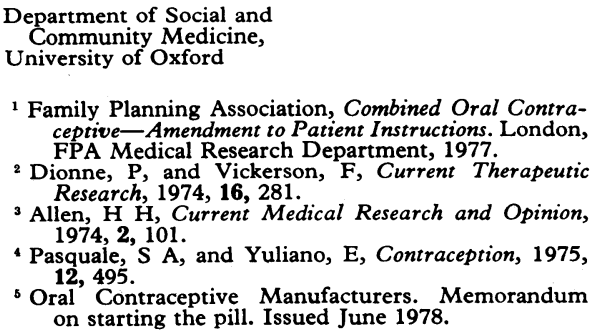

\section{Patient package inserts}

SIR,-With reference to your leading article (26 August, p 586) in which you state that critics of patient package inserts argue that, among other things, such inserts may "possibly diminish, rather than enhance, patients' compliance by making them afraid of adverse reactions" we would like to draw attention to our published work on this specific question.

In depressed patients treated with amitriptyline $^{1}$ and dothiepin ${ }^{2}$ we found no statistically significant difference in the compliance rates between patients who were warned about side effects and those who were not warned. In a further study ${ }^{3}$ we found that patients given written information about side effects of antidepressants had a significantly higher compliance rate than those given only verbal information or no information at all. We are currently investigating whether this is a cognitive effect or an "attention-placebo" effect.

E D MYERS

St Edward's Hospital,

E J CALVERT

\section{Leek, Staffs}

${ }^{1}$ Myers, E D, and Calvert, E J, British fournal of

Psychiatry, $1973,122,461$.
Myers, E D, and Calvert, E J, fournal of International Medical Research, 1976, 4, 237. Medical Research, 1976, 4, 237.
Myers, E D, and Calvert, E J, British fournal of
Psychiatry, 1978, 132, 526.

\section{Adverse reactions to intravenous induction agents}

SIR,-Dr H L Thornton (23 September, p 897) suggests that the role of the polyoxyethylated castor oil (Cremophor El) in which alphaxalone/alphadolone (Althesin) is made up should be investigated in adverse reactions to this intravenous induction agent. It has been established that Cremophor may play a part in severe histamine-mediated reactions to Althesin. ${ }^{1}$ However, it is not always the principal cause and in many cases is not implicated at all. ${ }^{2}$ In a case I recently reported intradermal skin testing proved conclusively that the reaction had developed to the Althesin alone and that the Cremophor was completely innocent.

Cambridge Military Hospital,

R H JAGO Aldershot, Hants

${ }^{1}$ Kessel, J, and Assem, E S K, British fournal of Anaesthesia, 1974, 46, 209

2 Fisher, M McD, Anaesthesia and Intensive Care, 1976, 4, 33.
3 Jago, R H, and Restall, J, Anaesthesia, 1978, 33, 644.

\section{Effect of quinidine on plasma} concentration of digoxin

SIR,-We would like to comment on the paper by Dr G Ejvinsson (4 February, p 279) concerning an important drug interaction between quinidine and digoxin. In accordance with his results we also found that the serum digoxin concentration rose in three hospital inpatients when digoxin was administered in combination with quinidine ( 3 tablets Kinidine Durettes twice daily, each tablet containing $250 \mathrm{mg}$ quinidine bisulphate).

A possible mechanism of this quinidinedigoxin interaction is a decrease of renal digoxin excretion during quinidine therapy. The influence of quinidine on the renal digoxin excretion was studied in these three patients by comparing the digoxin:creatinine renal clearance ratio on two days during and again on two days after quinidine therapy. The digoxin and creatinine clearances wer

assessed by collecting a 24-h urine sample and a midpoint blood sample. Digoxin concentrations in serum and urine (after dilution with buffer) were determined by ${ }^{125}$ I-digoxin radioimmunoassay (SchwarzMann kit). Quinidine or metabolites of quinidine did not influence the digoxin assay in serum and urine.

The results (see table below) indicate that quinidine inhibits renal digoxin clearance. The decrease of the renal digoxin clearance during quinidine therapy might explain the elevation of the serum digoxin concentration in these patients. Our data do not exclude the possibility that another mechanism may also be involved. Further study is required to investigate other mechanisms of this digoxinquinidine interaction.

Nevertheless our findings confirm the phenomenon published by Ejvinsson and we recommend careful observation of the serum digoxin concentration and the electrocardiogram when this combination of drugs is used.

\section{P M HOOYMANS}

\section{R C Hospital,}

Sittard, Netherland

F W H M MERKUS

Department of Biopharmaceutics,

University of Amsterdam,

Netherlands

\section{Health education in schools}

SIR,-Mrs Rosalind Cole (2 September, p 703) seems to be letting national pride blur her judgment. Health education has been an important subject in American schools and colleges for many years. In Britain the Schools Council and the Health Education Council are still trying to investigate the nature of the subject, so I do not think we can afford to look down on the American way of doing things.

In 20 years of teaching and mixing with teachers I have never come across anything resembling the rosy picture she paints of health education in Britain. Most children, I fear, leave school without even knowing the series of facts which Rosalind Cole despises so much. This is in part due to the ignorance of their "educators." How many British teachers know enough about toxocara, rabies, toxoplasmosis, tetanus, "non-accidental injury to children," the probable causes of ischaemic heart disease, etc?

It would appear to me self-evident that the first stage in a health education programme is to inform the teachers of the facts. The second stage is more problematic. It is pertinent to ask, "Is it ethical to try and manipulate the behaviour of children?" The problems of health education bear some resemblance to ethical problems. Children are likely to think that what teachers tell them about health merely reflects the feelings of the teacher. To overcome this some teachers may resort to

Digoxin:creatinine clearance ratios on two occasions during and on two occasions after quinidine treatment

\begin{tabular}{|c|c|c|c|c|c|c|}
\hline & \multicolumn{2}{|c|}{ Patient 1} & \multicolumn{2}{|c|}{ Patient 2} & \multicolumn{2}{|c|}{ Patient 3} \\
\hline & $\begin{array}{c}\text { During } \\
\text { quinidine } \\
\text { treatment }\end{array}$ & $\begin{array}{c}\text { After } \\
\text { quinidine } \\
\text { treatment }\end{array}$ & $\begin{array}{c}\text { During } \\
\text { quinidine } \\
\text { treatment }\end{array}$ & $\begin{array}{c}\text { After } \\
\text { quinidine } \\
\text { treatment }\end{array}$ & $\begin{array}{c}\text { During } \\
\text { quinidine } \\
\text { treatment }\end{array}$ & $\begin{array}{c}\text { After } \\
\text { quinidine } \\
\text { treatment }\end{array}$ \\
\hline 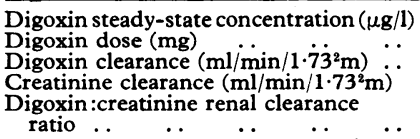 & \begin{tabular}{|c|}
$0.9 ; 1.0$ \\
0.25 \\
$74 ; 91$ \\
$79 ; 78$ \\
$0.94 ; 1.17$ \\
mean 1.05
\end{tabular} & $\begin{array}{c}0 \cdot 5 ; 0 \cdot 5 \\
0 \cdot 25 \\
139 ; 143 \\
98 ; 102 \\
1 \cdot 42 ; 1 \cdot 40 \\
\text { mean } 1 \cdot 41\end{array}$ & \begin{tabular}{|c|}
$2 \cdot 6 ; 2 \cdot 6$ \\
$0 \cdot 25$ \\
$43 ; 29$ \\
$88 ; 62$ \\
$0 \cdot 49 ; 0 \cdot 47$ \\
mean $0 \cdot 48$
\end{tabular} & $\begin{array}{c}1 \cdot 0 ; 1 \cdot 1 \\
0 \cdot 25 \\
66 ; 68 \\
71 ; 69 \\
0.93 ; 0.98 \\
\text { mean } 0.96\end{array}$ & \begin{tabular}{|l}
$1 \cdot 7 ; 1 \cdot 6$ \\
$0 \cdot 125$ \\
$42 ; 48$ \\
$61 ; 64$ \\
$0.69 ; 0.75$ \\
mean 0.72
\end{tabular} & $\begin{array}{c}1 \cdot 0 ; 1 \cdot 3 \\
0.125 \\
63 ; 54 \\
60 ; 55 \\
1.05 ; 0.98 \\
\text { mean } 1.02\end{array}$ \\
\hline
\end{tabular}


tactics summed up by Stevenson in his book Ethics and Language. ${ }^{1}$ Teachers may resort to emotive techniques in order to change the attitudes of children towards various methods of behaviour.

It is my opinion, however, that any attempt at crude emotivism will fail. We should present the children with the medical facts against a background of caring, now about their parents, later about their dependants.

V L IRWIN

St Edmund's College,

Ware, Herts

'Stevenson, C L, Ethics and Language. New Haven, Yale University Press, 1944.

\section{Flautist's chin: a companion to fiddler's neck}

SIR,-A 32-year-old female amateur flautist presented with a persistent eruption on her chin which had been present intermittently for two to three years. The only symptoms were of discomfort when playing the flute, but the eruption subsided if she stopped playing for two to three weeks. Examination revealed acneiform lesions confined to the central midportion of the chin consisting of inflammatory pustules, papules, and some slight hyperpigmentation. Elsewhere on the face there were a few inconspicuous open comedones and there was mild seborrhoea. She had not had significant acne as a teenager. Oxytetracycline 250 mg daily produced rapid improvement and she was able to toot her flute in complete comfort.

Peachey and Matthews ${ }^{1}$ described an acneiform eruption on the necks of violinists and viola players related to contact with and friction from their instruments. A similar situation pertains to the chins of flautists with the additional factor of constant wetting with saliva. "Flautist's chin" and "fiddler's neck" appear to be close companions in the acne orchestra demonstrating variations on the theme of acne mechanica. ${ }^{2}$ Perhaps more musical diseases such as "cellist's thigh" or "bagpiper's midriff" will yet be recorded.

\section{G C DAHL}

Dermatology Department,

Newcastle upon Tyne

${ }^{1}$ Peachey, R D G, and Matthews, C N A, British Pournal of Dermatology, 1978, 98, 669
fol

Mills, O H, and Kligman, A, Archives of Dermatology, 1975, 111, 481.

* * Examples of "guitar nipple," "guitarist's groin," and even "cello scrotum" were reported in these columns during 1974.-ED, $B M F$.

\section{Thyrotoxic Graves's disease after primary hypothyroidism}

SIR,-We were interested to see the report by $\mathrm{Dr} S$ Olczak and others (2 September $\mathrm{p}$ 666) of a patient who developed thyrotoxicosis after well-documented primary hypothyroidism, for we have recently seen a similar case.

Our patient, who is a female nursing office aged 56, was seen in 1975 complaining of increasing tiredness for one year, a husky voice, puffiness of the eyelids, mental and physical slowness, marked intolerance to the cold, and slight ataxia. There was no significant past history and there was no family history of thyroid disorder, diabetes mellitus, or pernicious anaemia. On examination she had a dry skin with a puffy face, typical of hypothyroidism, the pulse was $80 / \mathrm{min}$, there was slow relaxation of the deep reflexes, and the thyroid gland was not palpable. The serum thyroxine was $<10 \mathrm{mmol} / 1$ ( $<0.8 \mu \mathrm{g} / 100 \mathrm{ml})$, triiodothyronine $<0.1 \mathrm{mmol} / 1(<6.5 \mathrm{mg} / 100 \mathrm{ml})$, and thyroidstimulating hormone $80 \mathrm{mU} / \mathrm{l}$. She was started on thyroxine and soon regained her normal health, being maintained on $0.2 \mathrm{mg}$ daily.

She remained perfectly healthy for two years but in March 1978 she reported the loss of 1 stone $(6.4 \mathrm{~kg})$ in weight in spite of a good appetite and her colleagues had noted that she was nervous and jumpy. She was unusually tired in the hotter weather, but there was no excessive perspiration and no palpitations. She had noticed a little tremor. The serum thyroxine was $237 \mathrm{mmol} / \mathrm{l}$ tremor. The serum thyroxine was $237 \mathrm{mmol} / 1$ $(6.35 \mu \mathrm{g} / 100 \mathrm{ml})$, so the dosage of thyroxine was reduced and ultimately stopped. Six weeks after stopping thyroxine completely the symptoms continued and she was more hyperactive; the pulse was $88 / \mathrm{min}$, regular in rhythm; there was consider able swelling of the eyelids with minimal exoph thalmos, and slight lid retraction with lid-lag there was no pretibial myxoedema. The thyroid was just palpable on both sides. The serum thyroxine was $185 \mathrm{mmol} / \mathrm{l}(14.4 \mu \mathrm{g} / 100 \mathrm{ml})$ and triiodothyronine $6.0 \mathrm{mmol} / 1(0.39 \mu \mathrm{g} / 100 \mathrm{ml})$; thy roid autoantibodies were absent. She has been treated with carbimazole with marked improvement in her general symptoms, but there has been further aggravation of the exophthalmos. A thyroid scan, radioiodine uptake, and TRH-TSH stimulation tests were not performed. However, is clear clinically that she has now developed Graves's disease with exophthalmos and thyrotoxicosis and it is equally clear that she had history of hypothyroidism for at least one year before this diagnosis was established.

We have seen several patients who have had hypothyroidism and have then become euthyroid with a goitre typical of autoimmune thyroiditis, but we have not previously seen anyone develop frank hyperthyroidism and we have no further observations to explain this unusual phenomenon.

R B STOTT

Lewisham Hospital,

I S STAFFURTH London SE13

\section{Carcinoma of the breast in women under} the age of 30

SIR,-I was very interested to see the analysis by Mr A S Purandare and Dr J Finbow of the ages of their female patients with carcinoma of the breast ( 9 September, $p$ 771). In a somewhat smaller hospital than the Doncaster Royal Infirmary, serving a smaller population and sharing 60 general surgical beds, I have seen 213 female patients with the same condition. This is a very similar number to that seen by Mr Purandare and Dr Finbow in one year. The number of patients aged under 30 is the only significant difference in the age distribution in the two series (see table). Both series are small, but the incidence in this hospital of $1.4 \%$ aged under 30 agrees with the $1.2 \%$ figure given for Haagensen's very large number of cases.
It would appear that $\mathrm{Mr}$ Purandare and $\mathrm{Dr}$ Finbow have been unfortunate to have had so many young patients, but it was worth while to bring their findings to the attention of all doctors. The three patients under 30 in my series were not suspected of having malignant tumours and this was only discovered after biopsy. None of these patients has been shown to have metastases after several years.

\section{J H LOGAN}

Ulster Hospital,

${ }^{1}$ Haagensen, C D, Diseases of the Breast, 2nd edn, p 352. Philadelphia, Saunders, 1971.

\section{Hormone receptors in breast cancer}

SIR,-Your leading article (8 July, p 77) gives an excellent survey of the situation with respect to hormone receptors in breast cancer. As you note, some tumours may be composed of a mixed population of receptor-positive and receptor-negative cells; continued growth of negative cells would then lead to hormonal insensitivity. In fact, direct evidence that hormone-responsive mammary tumours are heterogeneous populations of cells has been obtained in studies of mammary cancer in mice $^{12}$ and rats. ${ }^{3}$ Endocrine ablation affects only the hormone-dependent cells in these tumours, leaving the hormone-independent cells intact. ${ }^{2}$ Progression from hormone dependence to autonomy in mammary tumours appears to be a manifestation of sequential clonal selection. ${ }^{1-3}$ It seems likely that the hormone-responsive human breast cancers also are mixed populations of hormone-dependent and -independent cells. Thus breast cancers which have been treated with hormones, hormonal ablation, or antioestrogens practically all recur after a certain period of time and ultimately all become autonomous. This indicates that the endocrine treatment only stops growth of the receptor-positive cells and not of the receptor-negative cells. Better therapeutic results with these cancers might be achieved by combining endocrine treatment at an early stage with chemotherapy, when the autonomous cells are still only few in number. In this way perhaps only low doses of cytostatics suffice to kill all the autonomous cells present in the tumour. It would be worth while to compare this form of treatment with the conventional form in which chemotherapy is not given until autonomous cells have been given the chance to form a sizable tumour and high doses of cytostatics have to be applied to achieve regression.

Lipmann et $a^{4}$ have reported that tumours with low or absent oestrogen receptor have a much higher response to chemotherapy than tumours with high oestrogen receptor values. They conclude that oestrogen receptor values are an important predictor of response to cytostatic chemotherapy. However, studies on mammary tumours in mice indicate that cytostatic treatment affects cells with different

Age distribution of women with carcinoma of the breast in two series

\begin{tabular}{|c|c|c|c|c|c|c|c|c|c|c|c|c|c|c|c|}
\hline \multirow[t]{2}{*}{ Age (years) } & \multicolumn{2}{|c|}{$20-30$} & \multicolumn{2}{|c|}{-40} & \multicolumn{2}{|c|}{-50} & \multicolumn{2}{|c|}{-60} & \multicolumn{2}{|c|}{-70} & \multicolumn{2}{|c|}{-80} & \multicolumn{2}{|c|}{$>80$} & \multirow[b]{2}{*}{ Total } \\
\hline & No & $\%$ & No & $\%$ & No & $\%$ & No & $\%$ & No & $\%$ & No & $\%$ & No & $\%$ & \\
\hline $\begin{array}{l}\text { Purandare } \\
\text { and Finbow } \\
\text { Logan .. .. }\end{array}$ & $\begin{array}{r}10 \\
3\end{array}$ & $\begin{array}{l}5 \cdot 1 \\
1 \cdot 4\end{array}$ & $\begin{array}{l}16 \\
20\end{array}$ & $\begin{array}{l}8 \cdot 2 \\
9 \cdot 4\end{array}$ & $\begin{array}{l}45 \\
43\end{array}$ & $\begin{array}{l}23 \cdot 1 \\
20 \cdot 2\end{array}$ & $\begin{array}{l}43 \\
53\end{array}$ & $\begin{array}{l}22 \cdot 1 \\
24 \cdot 9\end{array}$ & $\begin{array}{l}42 \\
46\end{array}$ & $\begin{array}{l}21 \cdot 5 \\
21 \cdot 6\end{array}$ & $\begin{array}{l}31 \\
38\end{array}$ & $\begin{array}{l}15 \cdot 9 \\
17 \cdot 8\end{array}$ & $\begin{array}{r}8 \\
10\end{array}$ & $\begin{array}{l}4 \cdot 1 \\
4 \cdot 7\end{array}$ & $\begin{array}{l}195 \\
213\end{array}$ \\
\hline
\end{tabular}

